\title{
Influence of Immediate Release Tablet Formulation on Dissolution Profile of Paracetamol
}

\author{
Nemanja B. Todorović ${ }^{1}$, Svetlana S. Goločorbin-Kon ${ }^{1}$, \\ Kristina N. Kermeci ${ }^{1}$, Jelena N. Jovičić Bata ${ }^{1}$, Nebojša M. Pavlović ${ }^{1}$, \\ Boris Ž. Milijašević ${ }^{2}$, Mladena N. Lalić-Popović ${ }^{1}$ \\ ${ }^{1}$ Department of Pharmacy, Faculty of Medicine Novi Sad, University of Novi Sad, Novi Sad, \\ Serbia \\ ${ }^{2}$ Department of Pharmacology and Toxicology, Faculty of Medicine Novi Sad, University of \\ Novi Sad, Novi Sad, Serbia
}

\section{SUMMARY}

Introduction: Paracetamol is analgesic and antipyretic, which is usually in the form of an immediate release tablet formulations. Therapeutic effects in terms of the speed and intensity of the analgesic effect is dependent on speed of liberation from formulation.

Aim: The aim of this work was to determine and compare dissolution profiles of 4 paracetamol immediate release tablet formulations and to determine influence of excipients on kinetic of paracetamol dissolution.

Materials and Methods: Dissolution profiles of paracetamol tablets were determined using method with paddles and phosphate buffer $\mathrm{pH} 6.8$ as a medium. Release of paracetamol was followed 60 minutes (using 6 time points). Concentration of paracetamol was measured using UV/Vis spectrophotometric method $(243 \mathrm{~nm})$. Dissolution profiles were compared using model-independent method (difference factor and similarity factor), statistic method (ANOVA-based method and pair Student's T-test, $p<0.05$ ) and model dependent methods (to determinate the release kinetics of paracetamol).

Results: All formulations in the first 45 minutes liberated more than $85 \%$ of the labled content. Formulation D, which contained superdesintegrator, released $90 \%$ of the content in the first 5 minutes. Though based on values of difference and similarity factors formulations are, not significantly different, ANOVA-based method showed that formulation $A$ and $B, B$ and $C$, as well as formulation $B$ and $D$ do statistically differ in all 6 time points, meaning they have parallel profiles. The release of paracetamol from formulations $A$ and $D$ is best described by the first order kinetic model, while the release of formulations $B$ and $C$ by the logistic model.

Conclusions: The release kinetic of paracetamol is mostly influenced by the type of superdisintegrants and lubricants. Formulation with superdisintegrant technology OptiZorb $^{\oplus}$ demonstrated fastes release rate and thus it is expected to produce the fastest pharmacodynamic effect.

Keywords: paracetamol, dissolution profiles, excipients, immediate release tablets 


\section{INTRODUCTION}

Absorption of the active pharmaceutical ingredient (API) from the solid dosage form after oral administration depends on the solubility and permeability of the API, as well as on the release of the API from the formulation. Further, the physicochemical features of the API, the composition and the excipients from the pharmaceutical-technological formulation have a significant influence on the release kinetics of the API. In vitro testing of dissolution profiles of API from immediate release (IR) solid formulations coud be used: 1) for the evaluation of product quality; 2) to assess the value of the product; 3 ) to control continuous quality and efficiency after changes in composition or production process, and 4) in the development of new formulations. In the development of the formulation, the dissolution testing assists in selecting excipients and optimizing the production process to ensure that the test product meets the quality of the reference product [1].

Paracetamol is an analgesic and antipyretic that is widely used in various pharmaceutical forms as an over-the-counter (OTC) drug. It is usually formulated in dose of 300$500 \mathrm{mg}$ in a form of IR tablets. On the market, paracetamol coud also be found in a formulation of syrup, suppository, tablets (uncoated, film-coated, effervescent), oral solution, powder for oral solution, powder for solution - sachet, solution for infusion [2]. According to the current Biopharmaceutical Classification System (BCS) paracetamol belongs to III group [3], meaning it has good solubility and low permeability [4].

Excipients of IR tablet formulation include fillers, binders, glidants and desintegrants. Paracetamol tableting mass is prepared usually by wet granulation since it contain high dose of paracetamol that has poor compressibility and low flowability $[5,6,7]$. The type of binder significantly influences hardness, and therefore the release of paracetamol from the tablet formulation $[8,9,10]$. IR tablet formulations also contain glidants (lubricants and anti-adhesives). These compounds are usually hydrophobic (e.g. magnesium stearate) and amount added as well as mixing time affect API release from tablets $[11,12]$.
AIM

It is cleare that excipients could greatly affect paracetamol relase from tablets which could lead to alteration in pharmacokinetic profile and therapeutic efficacy. Thus the aim of this study was to determine and compare the dissolution profiles of 4 IR tablet formulations of paracetamol as well as to estimate the effect of the pharmaceutical-technological formulation (excipients) on the paracetamol release kinetics of the tested tablet formulations.

\section{MATERIAL AND METHODS}

\section{Chemicals and devises}

Four randomly chosen paracetamol IR tablet formulations (dose $500 \mathrm{mg}$ ) that are on the market in Serbia were used in this study. Formulations A and B are uncoated immediate release tablets while formulations $\mathrm{C}$ and $\mathrm{D}$ are film-coated immediate release tablets. Pure 4-acetamidophenol (AlfaAesar, 98\%, Germany) was used for the calibration. Phosphate buffer was made by using of sodium dihydrogen phosphate (JTBaker, p.a, the Netherlands) and sodium chloride (JTBaker, p.a, Netherlands). Spectrophotometric recording was performed on the UV / VIS spectrophotometer (AgilentTechnologies, model 8453, USA). The dissolution profile was measured using the device 2 (paddle) on the Erweka model DT800. Technical balance (Radvag PS 450 / C / 2) and analytical balance (Radvag AS 220 / C / 2) were used too.

\section{UV / VIS spectrophotometry}

The release of paracetamol from tablet formulations as well as the content of paracetamol in tablets were determined using modified UV / Vis spectrophotometric method [13]. The spectrum was recorded in the range of 200 to $400 \mathrm{~nm}$. The paracetamol absorbance was measured at $243 \mathrm{~nm}$.

\section{Stock solution and method's calibration}

The stock solution was prepared by dissolving $10 \mathrm{mg}$ of paracetamol in $100 \mathrm{ml}$ phosphate buffer $\mathrm{pH} 6.8$ in a volumetric flask. The calibration curve was made by diluting the stock solution to obtain dilution series of 50,25 , $12.5,6.25 ; 3.125$ and $1.56 \mu \mathrm{g} / \mathrm{ml}$ were (Figure 
1). The calibration curve was linear in the observed range $\left(\mathrm{R}^{2}=0,9971\right)$.

\section{Dissolution testing}

Dissolution profiles were evaluated according to the United States Pharmacopoeia paddle method (Apparatus II) (USP41/NRF35). Six tablets were analyzed for each chosen formulation $(\mathrm{n}=6)$. The sampls were taken in 5,15 , $25,35,45$ and 60 minutes from the start of the analysis. The paddles were rotating at a speed of $50 \mathrm{rpm}$, the medium temperature was being $37 \pm 0.5^{\circ} \mathrm{C}$ and $5 \mathrm{ml}$ was sampled. Phosphate puffer $\mathrm{pH} 6.8$ was used as the dissolution medium. Sodium chloride was added in dissulution medium to adjust the ionic strength of in order to better imitate gastrointestinal tract conditions. Phosphate buffer $\mathrm{pH} 6.8$ was selected because paracetamol is highly soluble in it and thus solubility would not have effect on the dissolution profile but only the pharmaceutical formulation of the tested tablets [14].

\section{Sample preparation}

The concentration of paracetamol in the dissolution medium was determined by measuring on the UV / Vis spectrophrometer. One milliliter of dissolution sample was transfered into volumetric flask of $10 \mathrm{ml}$ and diluted with phosphate buffer $\mathrm{pH} 6,8$. After mixing, the solution was transferred to a quartz cuvette and the absorbance was measured at $243 \mathrm{~nm}$. The expected maximum concentration of paracetamol in the medium was $500 \mathrm{mg} / 900 \mathrm{ml}$ or $555.5 \mu \mathrm{g} / \mathrm{ml}$, i.e. after dilution 10 times 55.5 $\mu \mathrm{g} / \mathrm{ml}$. Blank test was a pure dissolution medium, or phosphate buffer $\mathrm{pH} 6.8$.

\section{Processing and displaying data}

The data are shown by tabular and graphical forms. The numerical values of the data are shown as the mean values \pm standard deviation. The calculations were made using the Microsoft Excel software for Windows 2007. The mean values were compared using a Paired Student's T-test and variance analysis (ANOVA), and the differences were considered significant if $\mathrm{p} \leq 0.05$. The software add-on for Microsoft Excel (DD solver) was used for statistical calculations as well as for modeling the obtained dissolution profiles.

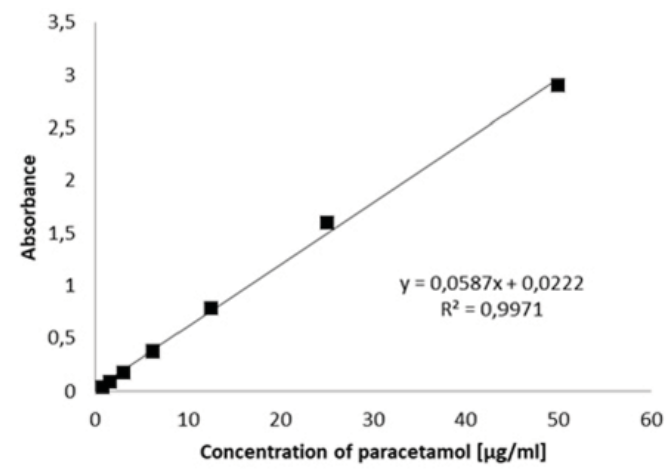

Figure 1. Calibration curve of paracetamol in phosphate buffer $\mathrm{pH} 6.8$

\section{Comparison of paracetamol's dissolution profiles}

The dissolution profiles were compared using the model independent method (similarity factor and difference factor), statistical methods (ANOVA test and paired T test) and model dependent method [15].

\section{Model independent method}

According to the guidelines of the US Food and Drug Administration (FDA) for the comparison dissolution profile IR tablets, it is recommended to use the difference factor (f1, equation 1 ) and the similarity factors (f2, equation 2) [16]. If the value of $\mathrm{f} 1$ is between $0-15$, and the value of $\mathrm{f} 2$ between 50 and 100 the observed profiles can be considered similar.

$$
\begin{aligned}
& f_{1}=\frac{\sum_{t=1}^{2}\left|R_{t}-T_{t}\right|}{\sum_{t=1}^{t} R_{t}} \\
& f_{2}=50 \log \left(\left|1+\frac{1}{2} \sum_{n=1}^{t}\left(R_{t}-T_{t}\right)^{2}\right|^{-0.5} x 100\right)
\end{aligned}
$$

Where $\mathrm{n}$ is the number of samples (in this study it is $n=6$ ), and the values of $\mathrm{Rt}$ and $\mathrm{Tt}$ are the cumulative procentage in of API in predetermined time point (referenc- $\mathrm{R}$ and test- $\mathrm{T}$ formulation).

\section{Model dependent method}

In the literature there are several mathematical models for describing the release kinetics of active pharmaceutical ingredient from solid dosage forms [15], and in this paper the following models were used: the model of the zero and first order kinetics [17], the HixsonCrowell cube root law [18], the Higuchi cube root model [19], Weibull's distribution [20], the Korsmeyer-Peppas model [21], and the Logistic Model [21].

Several parameters were used to se- 
lect the appropriate model: determination coefficient $\left(\mathrm{R}_{\mathrm{skr}}, \mathrm{R}^{2}\right)$, corrected determination coefficient $\left(\mathrm{R}_{\text {skr_adj }}\right)$, mean square error (MSE), Akaike Information Criterion (AIC) and Model Selection Criterion (MSC). The corrected determination coefficient depends on the number of parameters (formula 1) in the model and it decreases if it happens over fit [22]:

$$
R_{\text {adj }}^{2}=1-\frac{n-1}{n-p}\left(1-R^{2}\right)
$$

Where $\mathrm{n}$ is the number of data and $\mathrm{p}$ is the number of parameters in the model.

When it comes to the AIC parameter, it depends on the volume of data and the weighted sum of the squares (WSS), and it counts (formula 2):

$$
A I C=n * \ln (W S S)+2 * p
$$

Where $\mathrm{n}$ is the number of data, the WSS is the weighted sum of the squares, and $p$ is the number of parameters.

Based on an AIC value best fitted model is the one that has smallest AIC [22]. MSC is a statistical parameter which is in the fact modified reciprocal form of AIC value (formula 3). Model that has a highest MSC is best fitted. Generally, model where MSC has values more than two indicates a good match [22].

$M S C=\ln \frac{\sum_{i=1}^{n} w_{i} *\left(y_{i, o b s}-\bar{y}_{i, o b s}\right)^{2}}{\sum_{i=1}^{n} w_{i} *\left(y_{i_{-} \text {obs }}-y_{i_{-} p r e}\right)^{2}}-\frac{2 p}{n}$

Where wi is the weighting factor, and it usually is $1, \mathrm{y}_{\mathrm{i} \_ \text {obs }}$ is the $\mathrm{i}^{\text {th }}$ obtained value $\mathrm{y}$, $\mathrm{y}_{\mathrm{i}_{\mathrm{i} p \text { pred }}}$ is the $\mathrm{i}^{\text {th }}$ predicted value, $\bar{y}_{i_{\_} \text {obs }}$ is the mean value of the obtained $y$ values, $p$ is the number of parameters and $\mathrm{n}$ is the number of data [22].

\section{RESULTS AND DISCUSSION}

Figure 2 shows the rate of paracetamol release from tablet formulations $\mathrm{A}, \mathrm{B}, \mathrm{C}$ and $\mathrm{D}$ in phosphate buffer $\mathrm{pH} 6,8$. IR tablet formulations should have $85 \%$ of the content released within the first 45 minutes [16]. Using the model independent method, it was found that 4 tested dissolution profiles were similar (Table 1). However, values of the similarity factor- $\mathrm{f} 2$, although within the required range (50-100), were not relevant for comparing the profiles of the tested formulations, since the requirement is that at least two cumulative release percentage used for $\mathrm{f} 2$ calculation should be below $85 \%$ of the labelled content [16].

As can be seen in Figure 2, formulation $\mathrm{D}$ was the fastest, and released more than $85 \%$ of the content $(90.08 \pm 2.7 \%)$ in the first 5 minutes. Formulation A is the second (83.97 $\pm 4,05 \%)$, followed by formulation B (66.20 \pm $3.51 \%)$ and formulation $\mathrm{C}$ in the end (27.91 \pm
Figure 2. The dissolution profiles of formulations $A, B, C$ and $\mathrm{D}$ in phosphate buffer $\mathrm{pH} 6.8$

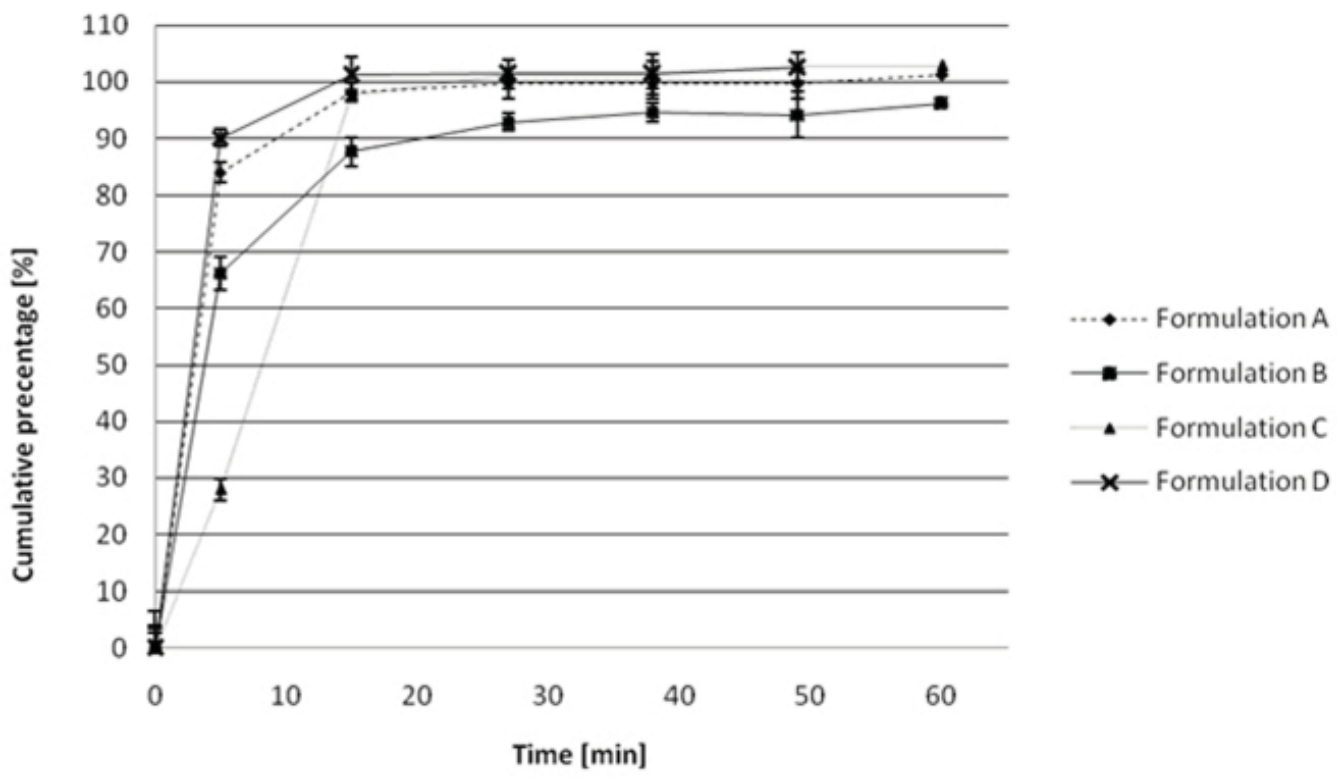




\begin{tabular}{|l|c|c|c|c|c|}
\hline & Formulation & A & B & C & D \\
\hline & A & $/$ & 0.087 & 0.110 & 0.200 \\
\hline Difference factor - f1 & B & 0.095 & $/$ & 0.148 & 0.296 \\
\hline & C & 0.147 & 0.120 & $/$ & 0.316 \\
\hline Similarity factor - f2 & D & 0.235 & 0.316 & 0.340 & $/$ \\
& A & $/$ & 50.68 & 31.95 & 19.10 \\
\hline & B & 50.68 & $/$ & 38.05 & 19.27 \\
\hline & C & 31.95 & 38.05 & $/$ & 15.46 \\
\hline
\end{tabular}

$6.54 \%)$. At 16 minutes, all the formulations released more than $85 \%$ of the content (formulation A $98.22 \pm 1.77$, formulation B $87.65 \pm$ 3.03 , formulation C $97.72 \pm 1.83$, and formulation $\mathrm{D} 101.11 \pm 2.7)$.

The fastest release of the active drug form from the formulation $\mathrm{D}$ can be explained by the contents of the formulation. It contains the so-called OptiZorb ${ }^{\circledR}$ technology, which represents a combination of calcium carbonate and alginic acid, the super-disintegrator related to the fast decomposition [23]. Alginic acid in the aquatic medium, rapidly absorbs water and swells, while calcium carbonate was predicted to react with the acid in the stomach,
Normality of distribution was tested using Shapiro-Wilk test (Table 2) for each time point. All data showed normal distribution.

Although the difference factors showed that the dissolution profiles of all 4 formulation are the same, the ANOVA test determined that the release in first 5 minutes of all the formulations were statistically different, except formulas A and D (Table 3). The percentage of the released paracetamol in tested time points statistically differs in all 6 points between formulation A and B (Table 3). Also, in all 6 time points, formulation $\mathrm{B}$ and $\mathrm{C}$ statistically differ, as well as $\mathrm{B}$ and $\mathrm{D}$. This means that these formulations have so-called paral-

\begin{tabular}{|c|c|c|c|c|c|c|}
\hline \multirow{2}{*}{ Formulation } & \multicolumn{7}{|c|}{ Time [min] } \\
\cline { 2 - 8 } & 5 & 16 & 27 & 38 & 49 & 60 \\
\cline { 2 - 8 } & \multicolumn{7}{|c|}{$\mathrm{P}$} \\
\hline A & 0,070 & 0,996 & 0,061 & 0,063 & 0,201 & 0,155 \\
\hline B & 0,136 & 0,995 & 0,213 & 0,823 & 0,727 & 0,880 \\
\hline C & 0,862 & 0,053 & 0,408 & 0,145 & 0,049 & 0,142 \\
\hline D & 0,687 & 0,881 & 0,060 & 0,478 & 0,521 & 0,521 \\
\hline
\end{tabular}

Table 2. Results of Shapiro-Wilk test

${ }^{*} \mathrm{p}<0,05$ presents normal distribution quickly decompose and release of API within 3 minutes $[24,25]$. When the tablet comes in GIT, the superdisintegrants comes in contact with digestive juices, which allows the tablet to decompose into smaller pieces from which the API could be more easily released, so it is expected that formulation $\mathrm{D}$ would perform quickest analgesic effect. lel profiles and are likely to exhibit different therapeutic effects (in terms of the rate and intensity of analgesic effect). Further analysis of the contents of the tested tablets has determined that the formulations $\mathrm{A}, \mathrm{B}$ and $\mathrm{C}$ are made by the method of wet granulation, while the formulation $\mathrm{D}$ is made with dry granulation method. It should also be noted that the

\begin{tabular}{|c|c|c|c|c|c|c|c|}
\hline \multirow{3}{*}{\multicolumn{2}{|c|}{ Formulation }} & \multicolumn{6}{|c|}{ Time [min] } \\
\hline & & 5 & 16 & 27 & 38 & 49 & 60 \\
\hline & & $F=25,352$ & $F=44,747$ & $F=18,208$ & $F=13,043$ & $F=13,145$ & $F=11,120$ \\
\hline A & B & 0,000 & 0,000 & 0,000 & 0,003 & 0,009 & 0,005 \\
\hline A & C & 0,000 & 0,981 & 0,664 & 0,584 & 0,257 & 0,36 \\
\hline A & D & 0,098 & 0,153 & 0,591 & 0,508 & 0,308 & I \\
\hline B & $\mathrm{C}$ & 0,000 & 0,000 & 0,000 & 0,000 & 0,000 & 0,001 \\
\hline B & D & 0,000 & 0,000 & 0,000 & 0,000 & 0,000 & I \\
\hline C & D & 0,000 & 0,075 & 0,999 & 0,999 & 0,999 & I \\
\hline
\end{tabular}

Table 3. Results of ANOVA analysis among formulations at 6 time points

* When $p<0.05$ there is a statistical difference 
formulations $\mathrm{C}$ and $\mathrm{D}$ are film-coated tablets, but with immediate release (this film material does not affect the rate of release, but only protects the tablet).

It is interesting to note that the most similar formulations in terms of composition are $\mathrm{A}$ and $\mathrm{B}$, however they dissolution profile were parallel. Both formulations contain microcrystalline cellulose $[6,25]$ as a filler, and croscarmellose sodium as a superdisintegrator. Microcrystalline cellulose is so called filler-binder that is compatible with most APIs and in contact with an aqueous medium, it swells and facilitates the release of API $[6,26]$. Formulation A contains magnesium stearate and castor oil as lubricants, talc as anti-adhesive and macrogol 6000 as a glidant. Also, the macrogol 6000 present in formulation A could additionally accelerate the dissolution of paracetamol, and gelatine (which is used as a binder) caused rapid decompose [11, 27-29]. Formulation B contains silicon dioxide as a glidant, and magnesium stearate as lubricant. Also the content of magnesium stearate could be higher in formulation $B$ than in formulation $\mathrm{A}$. The presence of povidone $\mathrm{K}-30$ as a binder, which could help in wetting, did not have a significant effect on the rate of release paracetamol in formulation $B$ [30].

Formulation $\mathrm{C}$ contains corn starch as a filler while as superdisintegrator contains pregelatinized starch [31]. During the compression there is a breakup of hydrogen bonds, so in the finished tablet there is a part of free amylose and free amylopectin. Free amylose is important for decomposition of tablets, while amylopectin helps with binding properties $[6,8]$. It should also be pointed out that starch is incompatible with magnesium stearate, and as glidants in formulation $\mathrm{C}$ was used talc and stearic acid [6]. This combination of two hydrophobic binders often is present in tablets, but at the same time it is responsible for the slowly release of the paracetamol from formulation $\mathrm{C}$ in the first 5 minutes. It lead to a changes in the characteristics of the tablet surface which lead to poor wetting, a complex decomposition, and then a reduced release of paracetamol $[11,32]$.

By examining the difference in percentage of the released paracetamol from the formulation among the time intervals within the same formulation, it was found that the release of the API in formulation A was completed after 16 minutes, in formulation $B$ after 38 minutes, in formulation $\mathrm{C}$ after 27 minutes, and in formulation $\mathrm{D}$ within 5 minutes (Table 4). These conclusions are based on the fact that after the mentioned time intervals there was no statistically significant difference between other compared time intervals (Table 4). The previously mentioned increased presence of magnesium stearate in formulation $B$, could also influence slower reach of paracetamol total content release [33]. Also, the presence of talc and stearic acid in formulation $\mathrm{C}$ could contribute to slowing release of paracetamol.

The profiles of the release of paracetamol from tablet formulations were also tested by a model dependent method to determine the paracetamol release kinetics. Determination of the optimal release model of API is of importance for the development of pharmaceutical formulation, quality control and the determination of the mechanism for the release of API from dosage form [34]. The selection of the appropriate model was based on the corrected determination coefficient ( Rskr $_{\text {adj }}$ ), where the model was better if the coefficient was closer to 1 . Also, the choice was made based on the AIC value that should be smaller, and the MSC value that should be larger [22]. Based on these parameters, it has been found that the release of paracetamol from formulations $\mathrm{A}$ and $\mathrm{D}$ best describes the model of the first order kinetics, while the release of paracetamol from formulations B and $\mathrm{C}$ best describes by the Logistic Model (Table 5). This means that the release of paracetamol from formulations $\mathrm{A}$ and $\mathrm{D}$ occurs mainly by diffusion, whereby the diffusion depends on the amount of the API left in the formulation. The Logistic Model corresponding to formulations $\mathrm{B}$ and $\mathrm{C}$ indicates that the release occurs by the diffusion so-called S-form, where, because of the value of the $\beta>1$ release function
Table 4. Student's T-test pairs, a comparison of the percentage of the release of paracetamol among the tested time intervals within the same formulation

\begin{tabular}{|c|c|c|c|c|c|}
\hline \multirow{2}{*}{ Formulation } & \multicolumn{5}{|c|}{-value for pairs } \\
\cline { 2 - 7 } & $5-16 \mathrm{~min}$ & $16-27 \mathrm{~min}$ & $27-38 \mathrm{~min}$ & $38-49 \mathrm{~min}$ & $49-60 \mathrm{~min}$ \\
\hline A & 0,003 & 0,463 & 0,968 & 0,966 & 0,396 \\
\hline B & 0,000 & 0,005 & 0,034 & 0,521 & 0,211 \\
\hline C & 0,000 & 0,016 & 0,980 & 0,325 & 0,364 \\
\hline D & 0,604 & 0,885 & 0,991 & 0,382 & $/$ \\
\hline
\end{tabular}




\begin{tabular}{|c|c|c|c|c|c|}
\hline & & A & B & C & D \\
\hline \multirow{6}{*}{$\begin{array}{l}\text { First-order } \\
\text { model }\end{array}$} & Rsqr & $0,92 \pm 0,07$ & $0,89 \pm 0,08$ & $0,89 \pm 0,12$ & $0,95 \pm 0,05$ \\
\hline & Rsqr adj & $0,92 \pm 0,07$ & $0,89 \pm 0,08$ & $0,89 \pm 0,12$ & $0,95 \pm 0,05$ \\
\hline & MSE & $112,28 \pm 97,14$ & $129,90 \pm 97,03$ & $221,91 \pm 245,63$ & $74,08 \pm 79,11$ \\
\hline & AIC & $39,47 \pm 16,61$ & $45,32 \pm 8,88$ & $44,04 \pm 12.49$ & $32,89 \pm 9,51$ \\
\hline & MSC & $1,53 \pm 2,32$ & $0,92 \pm 1,40$ & $1,67 \pm 1,06$ & $1,83 \pm 1,63$ \\
\hline & k1 & $0,22 \pm 0,09$ & $0,13 \pm 0,05$ & $0,21 \pm 0,11$ & $0,35 \pm 0,15$ \\
\hline \multirow{6}{*}{$\begin{array}{l}\text { Zero-order } \\
\text { model }\end{array}$} & Rsqr & $-62,32 \pm 46,81$ & $-13,48 \pm 5,48$ & $-25,96 \pm 62,52$ & $-102,92 \pm 45,08$ \\
\hline & Rsqr adj & $-62,32 \pm 46,81$ & $-13,48 \pm 5,48$ & $-25,96 \pm 62,52$ & $-102,92 \pm 45,08$ \\
\hline & MSE & $2413,15 \pm 262,77$ & $1752,59 \pm 118,39$ & $1382,48 \pm 322,74$ & $2798,80 \pm 81,76$ \\
\hline & AIC & $56,64 \pm 4,81$ & $56,46 \pm 0,41$ & $49,97 \pm 6,21$ & $48,61 \pm 0,15$ \\
\hline & MSC & $-4,31 \pm 0,63$ & $-2,95 \pm 0,38$ & $-1,45 \pm 0,38$ & $-4,96 \pm 0,46$ \\
\hline & k0 & $2,28 \pm 0,03$ & $2,15 \pm 0,03$ & $2,15 \pm 1,99$ & $2,81 \pm 0,06$ \\
\hline \multirow{6}{*}{ Higuchi model } & Rsqr & $-22,92 \pm 18,74$ & $-3,54 \pm 1,98$ & $-6,82 \pm 18,11$ & $-38,20 \pm 18,05$ \\
\hline & Rsqr adj & $-22,92 \pm 18,74$ & $-3,54 \pm 1,98$ & $-6,82 \pm 18,11$ & $-38,20 \pm 18,05$ \\
\hline & MSE & $898,01 \pm 118,08$ & $541,52 \pm 69,89$ & $413,37 \pm 110,62$ & $1043,97 \pm 60,85$ \\
\hline & AIC & $50,86 \pm 4,42$ & $49,38 \pm 0,78$ & $43,30 \pm 5,97$ & $43,68 \pm 0,29$ \\
\hline & MSC & $-3,32 \pm 0,65$ & $-1,77 \pm 0,44$ & $-0,24 \pm 1,98$ & $-3,97 \pm 0,50$ \\
\hline & kH & $16,28 \pm 0,22$ & $15,24 \pm 0,19$ & $16,09 \pm 0,68$ & $18,37 \pm 0,37$ \\
\hline \multirow{8}{*}{ Weibull model } & Rsqr & $0,80 \pm 0,12$ & $0,94 \pm 0,05$ & $0,87 \pm 0,05$ & $0,74 \pm 0,14$ \\
\hline & Rsqr adj & $0,67 \pm 0,19$ & $0,9 \pm 0,09$ & $0,78 \pm 0,07$ & $0,49 \pm 0,29$ \\
\hline & MSE & $14,01 \pm 6,37$ & $13,89 \pm 11,24$ & $176,72 \pm 103,71$ & $14,24 \pm 5,99$ \\
\hline & AIC & $27,01 \pm 4,35$ & $25,71 \pm 6,98$ & $36,50 \pm 11,53$ & $22,26 \pm 2,60$ \\
\hline & MSC & $0,78 \pm 0,71$ & $2,18 \pm 1,11$ & $1,08 \pm 9,45$ & $0,31 \pm 0,62$ \\
\hline & a & $0,90 \pm 0,18$ & $1,60 \pm 0,32$ & $10,19 \pm 7,38$ & $0,74 \pm 0,12$ \\
\hline & B & $0,23 \pm 0,06$ & $0,40 \pm 0,05$ & $0,84 \pm 0,34$ & $0,19 \pm 0,05$ \\
\hline & Td & $0,73 \pm 0,60$ & $3,50 \pm 1,16$ & $10,05 \pm 4,86$ & $0,27 \pm 0,24$ \\
\hline \multirow{6}{*}{$\begin{array}{l}\text { Hixson- } \\
\text {-Crowell } \\
\text { model }\end{array}$} & Rsqr & $-19,99 \pm 16,32$ & $-2,34 \pm 1,87$ & $-1,75 \pm 6,38$ & $-31,22 \pm 11,64$ \\
\hline & Rsqr adj & $-19,99 \pm 16,32$ & $-2,34 \pm 1,87$ & $-1,75 \pm 6,38$ & $-31,22 \pm 11,64$ \\
\hline & MSE & $796,82 \pm 94,71$ & $382,99 \pm 95,21$ & $136,69 \pm 76,98$ & $801,25 \pm 56,19$ \\
\hline & AIC & $50,16 \pm 4,15$ & $47,19 \pm 1,50$ & $36,17 \pm 8,34$ & $42,35 \pm 0,34$ \\
\hline & MSC & $-3,20 \pm 0,62$ & $-1,40 \pm 0,58$ & $1,10 \pm 2,30$ & $-3,81 \pm 0,41$ \\
\hline & $\mathrm{kHC}$ & $0,02 \pm 0,004$ & $0,02 \pm 0,001$ & $0,02 \pm 0,003$ & $0,03 \pm 0,002$ \\
\hline \multirow{7}{*}{$\begin{array}{l}\text { Korsmeyer- } \\
\text {-Peppas with } \\
\text { Tlag model }\end{array}$} & Rsqr & $0,78 \pm 0,11$ & $0,89 \pm 0,07$ & $0,67 \pm 0,16$ & $0,74 \pm 0,13$ \\
\hline & Rsqr adj & $0,63 \pm 0,17$ & $0,81 \pm 0,12$ & $0,41 \pm 0,25$ & $0,48 \pm 0,25$ \\
\hline & MSE & $16,08 \pm 5,63$ & $26,46 \pm 18,70$ & $539,11 \pm 349,44$ & $15,04 \pm 6,24$ \\
\hline & AIC & $27,98 \pm 3,46$ & $30,75 \pm 4,80$ & $41,76 \pm 14,91$ & $22,55 \pm 2,53$ \\
\hline & MSC & $0,61 \pm 0,52$ & $1,34 \pm 0,65$ & $0,13 \pm 0,53$ & $0,26 \pm 0,55$ \\
\hline & kKP & $80,38 \pm 5,12$ & $60,11 \pm 4,25$ & $31,65 \pm 26,80$ & $87,07 \pm 3,03$ \\
\hline & $\mathrm{n}$ & $0,06 \pm 0,02$ & $0,12 \pm 0,02$ & $0,38 \pm 0,18$ & $0,05 \pm 0,01$ \\
\hline \multirow{7}{*}{ Logistic model } & Rsqr & $0,81 \pm 0,12$ & $0,96 \pm 0,04$ & $0,91 \pm 0,05$ & $0,76 \pm 0,16$ \\
\hline & Rsqr adj & $0,68 \pm 0,19$ & $0,93 \pm 0,07$ & $0,85 \pm 0,08$ & $0,51 \pm 0,31$ \\
\hline & MSE & $13,07 \pm 6,74$ & $9,95 \pm 8,99$ & $106,23 \pm 77,35$ & $13,67 \pm 6,55$ \\
\hline & AIC & $26,43 \pm 4,91$ & $22,62 \pm 8,64$ & $33,91 \pm 11,97$ & $21,88 \pm 3,02$ \\
\hline & MSC & $0,89 \pm 0,83$ & $2,69 \pm 1,38$ & $1,56 \pm 0,75$ & $0,39 \pm 0,67$ \\
\hline & $a$ & $0,54 \pm 0,45$ & $-0,68 \pm 0,33$ & $-2,60 \pm 1,41$ & $0,89 \pm 0,35$ \\
\hline & B & $1,29 \pm 0,33$ & $2,05 \pm 0,22$ & $3,35 \pm 0,91$ & $1,19 \pm 0,28$ \\
\hline
\end{tabular}

Table 5. Parameters obtained by applying different models 
is sigmoidal with a reversal. It is interesting to note that formulations $\mathrm{A}$ and $\mathrm{B}$, although having a similar composition in terms of the fillers (microcrystalline cellulose) and superdisintegrants (croscarmellose), do not exhibit a similar drug release kinetics, indicating that other excipients (e.g., binders and glidants) determine the release profile of the drug from the formulation as well as the method of production.

This investigation of 4 commercially available IR formulations containing 500 $\mathrm{mg}$ of paracetamol showed that dissolution profiles are different and dependent on various aspects of formulation. By applying only model independent method the dissolution profiles seemed not to be statistically different, however statistical comparations showed there is significant differences in time point release between formulations. Also by applying the model dependent methods it was determined that the release kinetics of the formulations $\mathrm{A}$ and $\mathrm{D}$ correspond to the first order kinetics, that is, that the paracetmol is released by diffusion. Formulations B and C have the release of paracetamol corresponding to the Logistic Model. This shows the significant effect of the composition of the formulation on the paracetamol release kinetic.

Formulation D containing OptiZorb ${ }^{\circ}$ technology was expected to have quickest pain relief effect. It is interesting to note that the formulations A and B had the same fillers (microcrystalline cellulose) and superdisintegrants (sodium croscarmellose), but did not have the same rate release kinetic due to differences in the glidants. The presence of a higher amount of magnesium stearate in formulation $B$ affected its release profile, leading slower release and probably longer time in reaching pain relief effect.

\section{CONCLUSION}

This study highlights the influence of excipients such as desintegrants and lubricants on the release rate of paracetamol from four investigated OTC tablet formulation presented in the market. The onset of analgetic and antypiretic effect is related to the rate of paracetamol relese from tablets. Thus formulation with superdisintegrant technology OptiZorb ${ }^{\circledR}$ is expected to produce the fastest pain relief effect.

\section{ACKNOWLEDGEMENT}

This work has been supported by Ministry of Science and Technology development of Serbia $\mathrm{N}^{0} 41012$ III. The authors have no conflicts of interest that are directly relevant to the content of this study.

\section{CONFLICT OF INTEREST}

Nemanja Todorović declare no conflict of interest. Mladena Lalić-Popović declare no conflict of interest. Svetlana Goločorbin-Kon declare no conflict of interest. Kristina Kermeci declare no conflict of interest. Boris Milijašević declare no conflict of interest. Jelena Jovičić Bata declare no conflict of interest. Nebojša Pavlović declare no conflict of interest.

\section{REFERENCES}

1. Yuksel N, Kanik AE, Baykara T. Comparison of in vitro dissolution profiles by ANOVA-based, modeldependent and -independent methods. Int J Pharm. 2000;209:57-67.

2. Lekovi u prometu, priručnik o lekovima i njihovoj primeni, ATC klasifikacija, Ortomedics, Novi Sad, 2014.

3. Kalantzi L, Reppas C, Dressman JB, Amidon GL, Junginger HE, Midha KK, Shah VP, Stavchansky SA, Barends DM. Biowaiver monographs for immediate release solid oral dosage forms: Acetaminophen (paracetamol). J Pharm Sci. 2006;95(1):4-14.

4. Durić Z. Farmaceutska tehnologija sa biofarmacijom - I deo. Zemun: Nijansa; 2004.

5. Martinelo T, Kaneko TM, Velasco MV, Taquenda $\mathrm{ME}$, Consiglieri VO. Optimization of poorly compactable drug tablets manufactured by direct compression using the mixture experimental design. Int J Pharm. 2006;322(1-2):87-95.

6. Jivraj M, Martini LG, Thomson CM. An overview of the different excipients useful for the direct compression of tablets. Pharm Sci Technolo Today. 2000;3(2):58-63.

7. Hong-Guang W, Ru-Hua Z. Compaction behavior of paracetamol powders of different crystal shapes. Drug Dev Ind Pharm. 1995;21(7):863-8.

8. Ngwuluka NC, Idiakhoa BA, Nep El, Ogaji I, Okafor IS. Formulation and evaluation of paracetamol tablets manufactured using the dried fruit of Phoenix dactylifera Linn as an excipient. Res Pharm Biotech. 2010;2(3):025-32.

9. Krycer I, Pope DG, Hersey JA. An evaluation of tablet binding agents part I. Solution binders. Powder Technol. 1983;34(1):39-51. 
10. Troy DB and Paul Beringer. Remington: The Science and Practice of Pharmacy. Lippincont William \& Wilckins, Baltimor, USA, 2006.

11. Felton L. Remington: Essentials of pharmaceutics. Pharmaceutical Press, London, 2012.

12. Pifferi G, Santoro P, Pedrani M. Quality and functionality of excipients. II Farmaco. 1999;54(12):1-4.

13. Ashraful Islam SM, Paul PK. Validation of UVSpectrophotometric and RP-HPLC methods for the simultaneous analysis of Paracetamol and Aceclofenac in marketed tablets. Int. J. of Pharm. \& Life Sci. 201;2(12).

14. Heena F, Mamatha T, Zareena Y, Sutradhar S. Dissolution Method Development and Validation of Paracetamol - Aceclofenac Tablets. Int J Pharm Chem Sci. 2013;2(2):902-8.

15. Costa P, Lobo JM. Modeling and comparison of dissolution profiles. Eur J Pharm Sci. 2001;13(2):12333.

16. Guidance for Industry-Immediate Release Solid Oral Dosage Forms-Scale-Up and Postapproval Changes: Chemistry, Manufacturing, and Controls, in vitro Dissolution Testing, and in vivo Bioequivalence Documentation. Rockville. 1995.

17. Gibaldi M, Feldman S. Establishment of sink conditions in dissolution rate determinations. Theoretical considerations and application to nondisintegrating dosage forms. J Pharm Sci. 1967;56(10):1238-42.

18. Hixson AW, Crowell JH. Dependence of reaction velocity upon surface and agitation. Ind End Chem. 1931;23(8):923-31.

19. Higuchi T. Mechanism of sustained-action medication. Theoretical analysis of rate of release of solid drugs dispersed in solid matrices. J Pharm Sci. 1963;52(12):11.

20. Langenbucher F. Letters to the Editor: Linearization of dissolution rate curves by the Weibull distribution. J Pharm Pharmacol. 1972;24(12):979-81.

21. Rawlings JO. Applied Regression Analysis: A Research Tool. Belmont: Wadsworth, CA;1988.

22. Zhang Y, Huo M, Zhou J, Zou A, Li W, Yao C, Xie S. DDSolver: an add-in program for modeling and comparison of drug dissolution profiles. AAPS $\mathrm{J}$. 2010;12(3):263-71.

23. Wilson CG, Clarke CP, Starkey YY, Clarke GD. Comparison of a novel fast-dissolving acetaminophen tablet formulation (FD-APAP) and standard acetaminophen tablets using gamma scintigraphy and pharmacokinetic studies. Drug Dev Ind Pharm. 2011;37(7):747-53.

24. Lanvany B and Shanmugam V. Formulation and evaluation of bisoprolol fumarate optiyorb dispersible tablet to improve tablet disintegration. World
J Pharm Pharm Sci. 2015;4(1):561-76.

25. Gibson M. Pharmaceutical preformulation and formulation. 2nd edition. Informa healthcare. New Yourk. 2009.

26. Bolhuis GK, Lecker CF. Comparativ evaluation of excipents for direct compression. I. Pharmaceutical Weekbuilten.1973;108:469-81.

27. Klancke J. Dissolution testing of orally disintegrating tablets. Dissolut technol. 2003;10(2):6-9.

28. Mattsson S, Nyström C. Evaluation of critical binder properties affecting the compactibility of binary mixtures. Drug Dev Ind Pharm. 2001;27(3):18194.

29. Rudnic EM, Rhodes CT, Welch S, Bernardo P. Evaluations of the mechanism of disintegrant action. Drug Dev Ind Pharm. 1982;8(1):87-109.

30. Raymond C Rowe, Paul J Sheskey, Marian E Quinn. Handbook of Pharmaceutical Excipients. 16th edition. Pharmaceutical Press and American Pharmacists Association. 2009.

31. Shangraw RF, Dernarest DA. A survey of current industrial practice in the formulation and manufacture of tablet and capsules. Pharm Technol. 1993;17:32-8.

32. Augsburger L, Zellhofer M. Encyclopedia of Pharmaceutical Technology. Guiliford Pharmaceuticals. Inc. Baltimore. Maryland. 2007.

33. Desai DS, Rubitski BA, Varia SA, Newman AW. Physical interactions of magnesium stearate with starch-derived disintegrants and their effects on capsule and tablet dissolution. Int J Pharm. 1993;91(2-3):217-26.

34. Ilango KB and Kavimani S. Mathematical modeling of drug release from, colon site specific drug delivery systems. World J Pharm Pharm Sci. 2014;3(11):1051-64. 


\title{
Uticaj formulacije tableta sa trenutnim oslobađanjem na profil brzine rastvaranja paracetamola
}

\author{
Nemanja B. Todorović ${ }^{1}$, Svetlana S. Goločorbin-Kon ${ }^{1}$, Kristina N. Kermeci ${ }^{1}$, \\ Jelena N. Jovičić Bata ${ }^{1}$, Nebojša M. Pavlović ${ }^{1}$, Boris Ž. Milijaševićé, \\ Mladena N. Lalić-Popović ${ }^{1}$ \\ ${ }^{1}$ Katedra za farmaciju, Medicinski fakultet Novi Sad, Univerzitet u Novom Sadu, Novi Sad, Srbija \\ ${ }^{2}$ Katedra za farmakologiju i toksikologiju, Medicinski fakultet Novi Sad, Univerzitet u Novom Sadu, Novi \\ Sad, Srbija
}

\section{KRATAK SADRŽAJ}

Uvod: Paracetamol je analgetik i antipiretik koji se često formuliše u obliku tableta sa trenutnim oslobađanjem. Brzina i intenzitet terapeutskog efekta zavisi od brzine oslobađanja paracetamola iz tablete.

Cilj: Cilj ovog rada bio je da se ispitaju i uporede brzine osobađanja paracetamola iz četiri tabletne formulacije sa trenutnim osobađanjem i da se odredi uticaj pomoćnih supstanci na kinetiku osobađanja paracetamola iz tih formulacija.

Materijal i metode: Disolucioni profili paracetamola određeni su korišćenjem metode sa lopaticama i fosfatnim puferom $(\mathrm{pH} 6,8)$ kao medijumom za ispitivanje. Osobađanje paracetamola je praćeno tokom 60 min, u 6 vremenskih tačaka. Koncentracija paracetamola je određivana UV/Vis spektrofotometrijskom metodom $(243 \mathrm{~nm})$. Poređenje disolucionih profila rađeno je korišćenjem model-nezavisne metode (faktori razlike i sličnosti), statističkom metodom (ANOVA i T-test parova, $p<0.05$ ) i model zavisnim metodama (za određivanje kinetike osobađanja paracetamola).

Rezultati: Sve formulacija su oslobodije u prvih 45 minuta više od $85 \%$ deklarisanog sadržaja. Formulacija D, koja je u sastavu imala superdezintegrator, oslobodila je čak $90 \%$ deklarisanog sadržaja u prvih 5 minuta. lako vrednosti faktora razlike i sličnosti ( $f 1$ i f2) upućuju da su disolucioni profili isti, ANOVA testom pokazano je da se formulacije A i B, B i C, kao i B i D razlikuju u svih 6 ispitanih tačaka što znači da imaju paralelne profile. Dalje model zavisni metod je pokazao da oslobađanje paracetamola iz formulacije A i D najbolje opisuje model kinetike prvog reda, dok oslobađanje paracetamola iz formulacije B i C logistički model.

Zaključak: Kinetika osobađanja paracetamola najviše zavisi od vrste dezintegratora $i$ lubrikanata. Formulacija sa superdezintegrantskom tehnologijom OptiZorb ${ }^{\circledR}$ pokazala je najbržu stopu oslobađanja i kao rezultat toga se može očekivati i najbrži terapijski efekat.

Ključne reči: paracetamol, disolucioni profili, pomoćne supstance, tablete sa trenutnim osobađanjem 